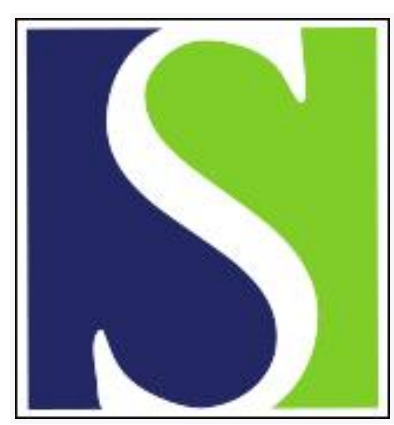

Scand J Work Environ Health 1993;19(6):405-413

https://doi.org/10.5271/sjweh.1454

Issue date: 01 Dec 1993

Minor effects of low exposure to inorganic mercury on the human immune system.

by Langworth S, Elinder CG, Sundqvist KG

Affiliation: Department of Occupational Medicine, Huddinge University Hospital, Sweden.

This article in PubMed: www.ncbi.nlm.nih.gov/pubmed/8153593

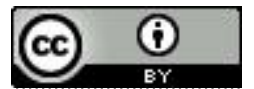




\title{
Minor effects of low exposure to inorganic mercury on the human immune system
}

\author{
by Sven Langworth, MD, ${ }^{1}$ Carl-Gustaf Elinder, MD, ${ }^{2}$ Karl-Gösta Sundqvist, $M^{3}$
}

\begin{abstract}
LANGWORTH S, ELINDER C-G, SUNDQVIST KG. Minor effects of low exposure to inorganic mercury on the human immune system . Scand J Work Environ Health 1993;19:405-13. The influence of exposure to inorganic mercury on the immune system was examined in 36 workers occupationally exposed to mercury vapor, 14 individuals with skin hypersensitivity to mercury compounds, 21 subjects with health disturbances allegedly caused by dental amalgam fillings ("amalgam disease"), and 39 healthy referents. Concentrations of mercury in blood and urine and some parameters judged to mirror different effects on the immune system were determined. The latter included, white blood cell differential counts, serum immunoglobulins and autoantibodies, and in vitro production of the cytokines interleukin 1 (IL-1) and tumor necrosis factor alpha (TNF $\alpha$ ). Virtually all of the immunologic parameters were within normal ranges and did not differ significantly between the groups. In the group sensitized to mercury, there was a reduction of the in vitro production of both TNF $\alpha$ and IL-1 compared with the reference group's values. No significant correlations were noted between different mercury exposure estimates and the immunologic parameters.
\end{abstract}

Key words: autoantibodies, cytokines, dental amalgam, immunoglobulins, immunological diseases, occupational exposure.

The central nervous system and the kidneys are well known "critical" organs with respect to exposure to inorganic mercury (1). During the last few decades also the effects of mercury on the immune system has attracted attention. Animal studies have demonstrated that several rodent species develop autoimmune manifestations, including glomerulonephritis, after injections of mercuric chloride (2). The induction of autoimmunity seems to be genetically restricted, and many strains (eg, Lewis rats) are resistant (2).

Experiments with Brown Norway (BN) rats, the most susceptible strain, show a transient production of serum autoantibodies to the glomerular basement membrane, and this production may be followed by membranous glomerulonephritis due to the deposition of autoantibodies and immune complexes along the glomerular basement membrane $(3,4)$. Autoimmune reactions appear in the $\mathrm{BN}$ rat in the context of a polyclonal activation of $B$ cells with an increase in both $B$ cells and CD4+ T cells, together with high serum levels of immunoglobulins (Ig), mainly $\operatorname{IgE}(5,6)$.

In susceptible strains of mice, long-term exposure to mercuric chloride induces high titers of antinuclear

1 Department of Occupational Medicine, Huddinge University Hospital, Huddinge, Sweden.

2 Department of Renal Medicine, Huddinge University Hospital, Huddinge, Sweden.

3 Department of Clinical Immunology, Huddinge University Hospital, Huddinge, Sweden.

Reprint requests to: Dr S Langworth, Department of Occupational Medicine, Huddinge Hospital, S-141 86 Huddinge, Sweden. antibodies (7). These autoantibodies and circulating immune complexes are involved in the glomerular IgG deposits found in the mesangium and the vessel walls, especially of mice carrying the $\mathrm{H}-2^{s}$ haplotype $(8,9)$.

Data on human immune reactions to inorganic mercury exposure are scarce. Skin hypersensitivity (Coombs type IV) to metallic mercury is rare (10), but some mercury salts, such as thiomersal and ammoniated mercury, have been found to be more common sensitizers (11). Cases of membranous glomerulonephritis have been described among workers exposed to inorganic mercury (12), and nephritis accompanied by the nephrotic syndrome has been observed in subjects using skin-lightening creams and drugs containing inorganic mercury $(13,14)$. However, the degree of exposure has not been clearly verified in these cases, and no dose-effect relationships have been established.

In Sweden and some other countries, there has been debate regarding the possible health effects of exposure to inorganic mercury released from dental amalgam fillings (15). The relatively low quantity of mercury absorbed from this source (16) has been proposed to induce an immune response in susceptible individuals and hence cause various symptoms (ie, "amalgam disease").

The main objective of this investigation was to examine possible effects of low exposure to inorganic mercury on the human immune system. The following three target groups were studied: (i) workers occupationally exposed to mercury vapor, (ii) individuals with skin hypersensitivity to inorganic mercury, and (iii) subjects with health disturbances attri- 
buted to mercury release from their dental amalgam fillings. Clinical data were collected together with information on a selection of parameters considered to mirror different effects on the immune system. In addition, the plasma selenium concentration and the erythrocyte activity of catalase and glutathione peroxidase were determined. Details regarding the latter parameters have been described in a separate report (17).

\section{Subjects and methods}

\section{Subjects}

The study population was composed of four groups. The first comprised 36 workers occupationally exposed to mercury in a chloralkali plant (14 male workers randomly selected from a group of about 25 daytime workers exposed to mercury), from a fluorescent light bulb factory (all 7 workers exposed to mercury at the plant: 5 men and 2 women), and from the dental service $(\mathrm{N}=15,6$ dentists and 9 dental nurses, all women, randomly selected at four dentistries). The average duration of exposure (ie, number of work-years) was 20 (range $1-45$ ) years.

The second group comprised 14 subjects (12 women and 2 men) with skin hypersensitivity to inorganic mercury. This "allergy group" consisted of individuals who had developed oral mucosal lesions (lichen orale) in conjunction with amalgam fillings and who had shown a positive reaction to mercury (metallic mercury, mercuric chloride or phenylmercury) in a patch test. All of these subjects were tested at the same dermatological department during a period of about 36 months. At the time of our study 12 subjects had had all of their amalgam fillings removed because of mercury hypersensitivity.

The third group comprised 21 subjects (16 women and 5 men) with health disturbances alleged to mercury release from their dental amalgam fillings ("amalgam group"). All of these subjects were referred to the department of occupational medicine by dentists for investigation of possible chronic mercury intoxication. Special selection criteria for this group were (i) chronic inconvenience for at least one year from three or more of the following symptoms: muscle or joint pain, abnormal tiredness, anxiety, gas- trointestinal disturbances, oral symptoms (sore mouth, metallic taste, etc, and tooth or jaw symptoms), memory impairment, loss of concentration, dizziness or vertigo, headache, or sleep disturbance; (ii) symptoms alleged to be caused by their own amalgam fillings; (iii) no occupational exposure to heavy metals or organic solvents; (iv) no overt mental illness or alcoholism; (v) primary examination having been made by a physician and dentist.

The fourth group was a reference group (30 women and 9 men) consisting of hospital personnel and office employees, not occupationally exposed to heavy metals or organic solvents.

Common selection criteria for all four groups were age between 20 and 70 years, no clinically apparent, untreated medical or odontological disease, no use of drugs known to interfere with the immune system, no acute infection at the time of the examination. There were no dropouts (ie, all of the subjects who were asked to participate joined the study). Details concerning age and some background data of the participants are presented in table 1 .

\section{Methods}

Data on the subjects' smoking habits, alcohol intake, fish consumption, work conditions, health history, and current medication were registered on a questionnaire. For 103 of the 110 individuals, the collected answers were checked in an interview with a physician (SL). In connection with the interview (or collection of the questionnaire) venous blood samples were drawn for analyses of immunologic parameters and mercury. In addition, dental amalgam burden (estimated as $0-5$ amalgam surfaces per each tooth with amalgam fillings) was judged by a physician.

Samples for analyses of lymphocyte deoxyribonucleic acid (DNA) synthesis and cytokine production, and for the prevalence of interleukin 2 (IL-2) receptors, were collected in sterile, heparinized, metal-free Vacutainer ${ }^{(1)}$ tubes (Becton Dickinson, Meylan Cedex, France). Samples for the determination of serum immunoglobulins and autoantibodies were collected in metal-free Vacutainer ${ }^{\boxplus}$ tubes, which were centrifuged to separate the blood cells. Samples for white blood cell counts were drawn into Vacutainer ${ }^{(8)}$

Table 1. Background characteristics of the four study groups.

\begin{tabular}{|c|c|c|c|c|c|c|c|c|c|c|}
\hline \multirow[t]{2}{*}{ Group } & \multirow{2}{*}{$\begin{array}{c}\text { Number } \\
\text { of } \\
\text { subjects }\end{array}$} & \multicolumn{2}{|c|}{$\begin{array}{c}\text { Age } \\
\text { (years) }\end{array}$} & \multicolumn{2}{|c|}{$\begin{array}{c}\text { Fish intake } \\
\left.\text { (meals } \cdot \text { week }^{-1}\right)\end{array}$} & \multicolumn{2}{|c|}{$\begin{array}{c}\text { Alcohol } \\
\text { consumption } \\
\left(\mathrm{cl} \cdot \text { week }^{-1}\right)\end{array}$} & \multicolumn{2}{|c|}{$\begin{array}{l}\text { Amaigam surfaces } \\
(\mathrm{N})\end{array}$} & \multirow[t]{2}{*}{$\begin{array}{c}\text { Smoking } \\
(\%)\end{array}$} \\
\hline & & Mean & SD & Mean & SD & Mean & SD & Mean & SD & \\
\hline Reference & 39 & 40.0 & 8.3 & 1.6 & 0.8 & 11.7 & 15.0 & 32.2 & 14.4 & 33 \\
\hline Exposed & $36^{a}$ & 46.4 & 9.4 & 1.6 & 0.9 & 11.8 & 15.2 & 27.6 & 18.1 & 28 \\
\hline Allergy & 14 & 53.9 & 8.3 & 1.3 & 0.6 & 5.1 & 4.5 & 2.6 & 5.4 & 14 \\
\hline Amalgam & 21 & 47.4 & 11.1 & 1.2 & 0.6 & 4.4 & 6.8 & 26.7 & 15.4 & 43 \\
\hline
\end{tabular}

a $\mathrm{N}=29$ regarding amalgam surfaces. 
tubes prepared with ethylenediaminetetraacetic acid (EDTA). Blood samples for lymphocyte transformation tests (LTT) (performed for 18 subjects) were drawn into metal-free, sterile Vacutainer ${ }^{\circledR}$ tubes with polystyrene granules. These tubes were gently shaken for $10 \mathrm{~min}$ to prevent coagulation.

Samples for the whole blood and plasma mercury analyses were collected in metal-free, heparinized Vacutainer $\left.^{(}\right)$tubes. Morning urine samples were collected at home by each subject in $250-\mathrm{ml}$ acidwashed polyethylene bottles which were delivered to the Department of Occupational Medicine within 4$5 \mathrm{~h}$. All of the mercury samples were then frozen at $-20^{\circ} \mathrm{C}$, and stored for about four months until the analyses.

\section{Analyses of the immunologic parameters}

All of the immunologic analyses except the LTT were performed in the Department of Clinical Immunology of the Huddinge University Hospital. For a more-detailed description of the methods used, see reference 18 .

White blood cell counts and urinary creatinine were determined at the Department of Clinical Chemistry of the same hospital with the use of standard methods. In every series of immunologic analyses samples from both "target" subjects and referents were included, but the analyses were performed without knowledge of the group to which the individuals belonged.

Serum concentrations of $\operatorname{IgA}, \operatorname{IgG}$, and $\operatorname{IgM}$ were determined by nephelometry (Beckman Array Protein System), and the IgE concentration in serum with the Phast system (Pharmacia, Sweden).

Serum autoantibodies to various tissue antigens were determined by indirect immunofluorescence using tissue sections of rat kidney and stomach as the antigen. Anti-DNA antibodies were determined in all sera positive for antinuclear antigens, critidae luciliae being used as the antigen. Antibodies to the glomerular basement membrane were determined by the "anti-Goodpasture" enzyme immunoassay (Biocarb Diagnostics AB, Lund, Sweden). Antibodies against thyroid microsomal antigen and thyroglobulin were analyzed with hemagglutination tests from Wellcome laboratories (Dartford, England).

The purification of mononuclear cells started within $5 \mathrm{~h}$ of the blood sampling. Mononuclear cells were isolated by lymphoprep centrifugation (Nycomed Pharma, Oslo, Norway). In order to study cytokine production in vitro, the mononuclear cells were cultured overnight in conditioned media in the absence and presence of lipopolysacaride.

Spontaneous and ConA-induced DNA synthesis (Con $\mathrm{A}=$ convanvalin $\mathrm{A}$ ) were determined as described by Soop et al (19). The cytokines interleukin 6 (IL-6), interleukin 1 (IL-1), and tumor necrosis factor alpha (TNF $\alpha$ ) were analyzed in serum (IL-6) and conditioned media (IL-1 and TNF $\alpha$ ) with commer- cial enzyme immunoassays (Medgenix Diagnostics EASIA).

For the determination of IL-2 receptors, lymphocytes attached to glass cover slips were reacted with monoclonal antibodies directed against $\mathrm{CD} 3$, CD4, CD8, CD14, and CD25 (CD = cluster of differentiation). The reactivity of the monoclonal antibodies was subsequently detected with a biotin-avidin peroxidase system (Vector Laboratories, Burlingame, California, United States).

The in vitro responsiveness of peripheral blood lymphocytes to mercuric chloride and phenylmercury acetate was determined in 10 subjects occupationally exposed to mercury, in nine subjects with skin hypersensitivity to mercury, and in 10 subjects belonging to the amalgam group. These persons were randomly selected. The analyses (LTT) were performed at the Laboratory of Immunotoxicology, Astra AB (Södertälje, Sweden) with the method described by Stejskal et al (20).

\section{Mercury exposure estimates}

The immunologic parameters were related to the following five exposure indicators: (i) current concentration of mercury in blood, plasma and urine (adjusted for creatinine excretion measured with Jaffe's colorometric method); (ii) exposure duration (number of work-years with mercury exposure); (iii) exposure intensity (low or high level of mercury exposure, determined according to the employee's work type and their expected mercury exposure, as judged by one of the researchers); (iv) fish consumption (number of fish meals per week and type of fish); (v) amalgam burden (estimated as $0-5$ amalgam surfaces per tooth with amalgam fillings). In the three groups occupationally unexposed to mercury (reference group, allergy group, amalgam group), the immunologic parameters were related to the first, fourth and fifth exposure indicators. Fish consumption was included as an indicator of background exposure to methylmercury.

The concentration of total mercury in whole blood, plasma, and urine was analyzed in the laboratory of the Division of Medical Chemistry at the Swedish National Institute of Occupational Health. A modified version of cold-vapor atomic absorption spectrophotometry was used. For details concerning the methods and quality control of the mercury analyses see reference 21 .

The mercury concentrations in whole blood (B-Hg), plasma (P-Hg), and urine (U-Hg) of the four study groups are presented in table 2 . The highest mercury levels were seen among the chloralkali workers (median B-Hg $35 \mathrm{nmol} \cdot \mathrm{I}^{-1}$, median $\mathrm{U}-\mathrm{Hg} 7.22 \mathrm{nmol}$. mmol creatinine ${ }^{-1}$ ), whereas the dental personnel and the workers in the light bulb factory had only slightly elevated mercury levels (median B-Hg $16 \mathrm{nmol} \cdot \mathrm{l}^{-1}$, median U-Hg $1.86 \mathrm{nmol} \cdot \mathrm{mmol}$ creatinine $^{-1}$ ) when they were compared with the referents. 
Table 2. Current concentration of mercury in whole blood $(\mathrm{B}-\mathrm{Hg})$, plasma $(\mathrm{P}-\mathrm{Hg})$, and urine $(\mathrm{U}-\mathrm{Hg})$ in the four study groups.

\begin{tabular}{|c|c|c|c|c|c|c|c|}
\hline \multirow{2}{*}{ Group } & \multirow{2}{*}{$\begin{array}{l}\text { Number } \\
\text { of } \\
\text { subjects }\end{array}$} & \multicolumn{2}{|c|}{$\begin{array}{c}\mathrm{B}-\mathrm{Hg} \\
\left(\left.\mathrm{nmol} \cdot\right|^{-1}\right)\end{array}$} & \multicolumn{2}{|c|}{$\begin{array}{c}\mathrm{P} \cdot \mathrm{Hg} \\
\left(\mathrm{nmol} \cdot \mathrm{I}^{-1}\right)\end{array}$} & \multicolumn{2}{|c|}{$\begin{array}{c}\mathrm{U}-\mathrm{Hg} \\
\left(\mathrm{nmol} \cdot \mathrm{mmol} \text { creatinine }{ }^{-1}\right)\end{array}$} \\
\hline & & Median & Range & Median & Range & Median & Range \\
\hline $\begin{array}{l}\text { Reference } \\
\text { Exposed } \\
\text { Allergy } \\
\text { Amalgam }\end{array}$ & $\begin{array}{l}39 \\
36 \\
14 \\
21\end{array}$ & $\begin{array}{r}11 \\
21 \\
6 \\
10\end{array}$ & $\begin{array}{l}5-35 \\
6-125 \\
1-27 \\
3-37\end{array}$ & $\begin{array}{l}5 \\
8 \\
2 \\
4\end{array}$ & $\begin{array}{l}0-13 \\
2-92 \\
0-13 \\
1-15\end{array}$ & $\begin{array}{l}1.25 \\
2.80 \\
1.00 \\
1.86\end{array}$ & $\begin{array}{l}0.35-5.80 \\
0.63-12.60 \\
0.36-2.43 \\
0.61-4.00\end{array}$ \\
\hline
\end{tabular}

Table 3. Total white blood cell counts (in randomly selected subgroups) and differential counts in the four study groups.

\begin{tabular}{|c|c|c|c|c|c|c|c|c|c|c|c|c|c|c|}
\hline \multirow{3}{*}{ Group } & \multicolumn{3}{|c|}{$\begin{array}{l}\text { Total white } \\
\text { cells }\left(10^{9} \cdot \mid-1\right)\end{array}$} & \multicolumn{11}{|c|}{ Differential counts $(\%)$} \\
\hline & \multirow{2}{*}{$\begin{array}{c}\text { Number } \\
\text { of } \\
\text { subjects }\end{array}$} & \multirow{2}{*}{ Mean } & \multirow{2}{*}{ SD } & \multirow{2}{*}{$\begin{array}{c}\text { Number } \\
\text { of } \\
\text { subjects }\end{array}$} & \multicolumn{2}{|c|}{ Lymphocytes } & \multicolumn{2}{|c|}{ Monocytes } & \multicolumn{2}{|c|}{ Neutrophils } & \multicolumn{2}{|c|}{ Eosinophils } & \multicolumn{2}{|c|}{ Basophils } \\
\hline & & & & & Mean & $\mathrm{SD}$ & Mean & $S D$ & Mean & SD & Mean & SD & Mean & SD \\
\hline Reference & 19 & 6.5 & 1.7 & 39 & 35.8 & 12.3 & 5.4 & 2.7 & 54.6 & 12.3 & 3.5 & 2.7 & 0.9 & 0.8 \\
\hline Exposed & 19 & 6.7 & 2.1 & $32^{a}$ & 36.0 & 10.1 & 6.2 & 2.7 & 54.3 & 11.4 & 2.9 & 2.3 & 0.6 & 0.7 \\
\hline Allergy & 14 & 6.1 & 2.3 & 14 & 37.1 & 11.7 & 6.6 & 2.1 & 52.9 & 11.2 & 2.7 & 1.6 & 0.6 & 0.8 \\
\hline Amalgam & 10 & 6.3 & 1.0 & $19^{b}$ & 33.4 & 9.3 & 6.1 & 3.3 & 56.0 & 9.6 & 3.3 & 2.0 & 1.3 & 1.2 \\
\hline
\end{tabular}

a Four subjects excluded due to bad smears.

- Two subjects excluded due to bad smears.

Table 4. Immunoglobulin (Ig) concentrations in serum in the four study groups.

\begin{tabular}{|c|c|c|c|c|c|c|c|c|c|}
\hline \multirow[t]{2}{*}{ Group } & \multirow{2}{*}{$\begin{array}{c}\text { Number } \\
\text { of } \\
\text { subjects }\end{array}$} & \multicolumn{2}{|c|}{$\begin{array}{c}\lg A \\
\left(\left.g \cdot\right|^{-1}\right)\end{array}$} & \multicolumn{2}{|c|}{$\begin{array}{c}\lg G \\
\left(\left.g \cdot\right|^{-1}\right)\end{array}$} & \multicolumn{2}{|c|}{$\begin{array}{c}\lg M \\
(g \cdot \mid-1)\end{array}$} & \multicolumn{2}{|c|}{$\left(\left.U^{\lg E}\right|^{-1}\right)$} \\
\hline & & Mean & SD & Mean & SD & Mean & $S D$ & Mean & SD \\
\hline $\begin{array}{l}\text { Reference } \\
\text { Exposed } \\
\text { Allergy } \\
\text { Amalgam }\end{array}$ & $\begin{array}{l}39 \\
36 \\
14 \\
21\end{array}$ & $\begin{array}{l}1.9 \\
2.0 \\
2.2 \\
2.2\end{array}$ & $\begin{array}{l}0.7 \\
0.9 \\
1.0 \\
1.1\end{array}$ & $\begin{array}{l}10.8 \\
10.5 \\
10.8 \\
11.2\end{array}$ & $\begin{array}{l}2.2 \\
2.3 \\
2.0 \\
2.3\end{array}$ & $\begin{array}{l}1.6 \\
1.2 \\
1.2 \\
1.5\end{array}$ & $\begin{array}{l}0.7 \\
0.5 \\
0.6 \\
0.7\end{array}$ & $\begin{array}{l}30.3 \\
24.5 \\
50.9 \\
21.6\end{array}$ & $\begin{array}{l}48.6 \\
39.7 \\
74.2 \\
26.9\end{array}$ \\
\hline
\end{tabular}

\section{Statistical methods}

Comparisons of the examined parameters between the three target groups and the reference group were made with the two-sided Student's t-test or the Mann-Whitney rank sum test (for skewed parameters). Dose-effect relationships were studied with Pearson's correlation coefficient or with Spearman's rank correlation coefficient (for skewed parameters) and by multiple regression. The influence of age, gender, smoking, alcohol intake, and sampling occasion on the immunologic parameters was examined in an analysis of variance (ANOVA).

\section{Results}

\section{White blood cell counts}

The total white blood cell counts did not differ significantly between the groups. Nor did the percentage of white cells in the differential counts vary between the groups (table 3 ). In the total population $(\mathrm{N}=110)$, there was a significant correlation $(\mathrm{r}=$ $0.32, \mathrm{P}=0.001$ ) between the percentage of eosinophils and the IgE levels in serum. No other nota- ble relationships were seen between the white blood cell counts and the different immune parameters or the mercury exposure estimates.

\section{Immunoglobulins}

The serum concentrations of $\operatorname{IgA}, \operatorname{IgG}, \operatorname{IgM}$, and $\operatorname{IgE}$ were normal in all four groups, although the subjects in the allergy group had somewhat higher IgE values (table 4). In the total population, the smokers exhibited slightly higher IgE levels than the nonsmokers $(P=0.063)$. There were no significant correlations between the immunoglobulin levels and the mercury exposure estimates.

\section{Autoantibodies}

The number of sera containing autoantibodies against the different tissue antigens was low in all four groups (table 5). The relative frequency of sera with detectable autoantibodies to one or more of the different antigenic specificities tested was $4.8 \%$ (17 of 357 ) in the reference group, $5.4 \%$ (18 of 332 ) in the exposed group, $3.9 \%$ (5 of 129) in the allergy group, and $3.2 \%$ (6 of 190) in the amalgam group. The prevalence of antithyroid antibodies was somewhat elevated in the amalgam group when compared with the corresponding values of the reference group (4 positive out of 21 versus 2 out of $39, P=0.11$ in Fisher's test). The workers exposed to mercury did not show elevated titers of autoantibodies against antigens (glomeruli or glomerular basement membrane) associated with mercury-induced glomerulonephritis in animal models (2). None of the subjects with elevated antinuclear antigen titers displayed serum autoantibodies to DNA. 
Table 5. Number of subjects with detectable serum autoantibodies to the different tissue antigens tested. (ANA = antinuclear antigen, DNA = deoxyribonucleic acid, IIF = indirect immunofluorescence test, $\mathrm{HA}=$ hemagglutination test, $\mathrm{GBM}=\mathrm{glomerular}$ basement membrane, ELISA = enzyme-linked immunosorbent assay)

\begin{tabular}{|c|c|c|c|c|c|}
\hline \multirow[b]{2}{*}{ Tissue spec } & \multirow{2}{*}{$\begin{array}{c}\text { Method } \\
\text { of } \\
\text { determination }\end{array}$} & \multicolumn{4}{|c|}{ Group } \\
\hline & & $\begin{array}{l}\text { Reference } \\
(\mathrm{N}=37)^{\mathrm{a}}\end{array}$ & $\begin{array}{l}\text { Exposed } \\
(\mathrm{N}=36)\end{array}$ & $\begin{array}{l}\text { Allergy } \\
(\mathrm{N}=14)\end{array}$ & $\begin{array}{c}\text { Amalgam } \\
(\mathrm{N}=21)\end{array}$ \\
\hline ANA & IIF & & & & \\
\hline 10 titers $^{-1}$ & & 1 & - & 2 & - \\
\hline 25 titers $^{-1}$ & & 4 & 4 & - & - \\
\hline 100 titers $^{-1}$ & & - & 4 & - & - \\
\hline$\geq 400$ titers $^{-1}$ & & 1 & - & 1 & 1 \\
\hline DNA & IIF & & & & \\
\hline 10 titers $^{-1}$ & & - & - & - & - \\
\hline 25 titers $^{-1}$ & & - & - & - & - \\
\hline 100 titers $^{-1}$ & & - & - & - & - \\
\hline$\geq 400$ titers $^{-1}$ & & - & - & - & - \\
\hline Smooth muscle & IIF & & & & \\
\hline 10 titers $^{-1}$ & & - & 1 & - & - \\
\hline 25 titers $^{-1}$ & & 1 & 2 & - & - \\
\hline 100 titers $^{-1}$ & & 3 & 1 & 1 & - \\
\hline$\geq 400$ titers $^{-1}$ & & - & - & - & - \\
\hline Reticulin & IIF & & & & \\
\hline 10 titers $^{-1}$ & & - & - & - & - \\
\hline 25 titers $^{-1}$ & & - & - & - & - \\
\hline 100 titers $^{-1}$ & & - & 2 & - & - \\
\hline$\geq 400$ titers $^{-1}$ & & - & - & - & - \\
\hline Glomeruli & IHF & & & & \\
\hline 10 titers $^{-1}$ & & - & - & - & - \\
\hline 25 titers $^{-1}$ & & 1 & - & - & - \\
\hline 100 titers $^{-1}$ & & - & - & - & - \\
\hline$\geq 400$ titers $^{-1}$ & & 1 & - & - & - \\
\hline Mitochondria & IIF & & & & \\
\hline 10 titers $^{-1}$ & & - & 1 & - & - \\
\hline 25 titers $^{-1}$ & & - & - & - & - \\
\hline 100 titers $^{-1}$ & & - & - & - & - \\
\hline$\geq 400$ titers $^{-1}$ & & - & - & - & - \\
\hline Parietal cells & $\| \mathrm{F}$ & & & & \\
\hline 10 titers $^{-1}$ & & - & - & - & - \\
\hline 25 titers $^{-1}$ & & - & 1 & - & $=$ \\
\hline 100 titers $^{-1}$ & & 1 & 1 & - & - \\
\hline$\geq 400$ titers $^{-1}$ & & 1 & - & - & - \\
\hline Thyroglobulin & $\mathrm{HA}$ & & & & \\
\hline 20 titers $^{-1}$ & & 1 & 1 & - & 1 \\
\hline 40 titers $^{-1}$ & & - & - & - & - \\
\hline 80 titers $^{-1}$ & & - & - & - & - \\
\hline$\geq 160$ titers $^{-1}$ & & - & - & $\overline{1}$ & - \\
\hline $\begin{array}{l}\text { Thyroid (micro- } \\
\text { somal antigen) }\end{array}$ & $\mathrm{HA}$ & & & & \\
\hline 200 titers $^{-1}$ & & 2 & 1 & - & 2 \\
\hline$\geq 400$ titers $^{-1}$ & & - & - & - & 2 \\
\hline $\mathrm{GBM}^{\mathrm{b}}$ & ELISA & & & & \\
\hline$>10$ units & & - & - & - & - \\
\hline
\end{tabular}

a Serum lacking from two individuals.

b $>10$ units considered a positive reaction (ie, presence of antibodies).

\section{Deoxyribonucleic acid synthesis}

The spontaneous ${ }^{3} \mathrm{H}$-thymidine uptake (DNA synthesis) in the four groups investigated is shown in figure 1. There were no statistically significant group differences. In the amalgam group, the DNA synthesis was extremely high in a single individual (27 363 counts $\left.\cdot \mathrm{min}^{-1}\right)$. In the reference group, spontaneous DNA synthesis was statistically significantly correlated to age $(\mathrm{r}=-0.33, \mathrm{P}=0.015)$ and to the mer- cury level in plasma $(\mathrm{r}=0.43, \mathrm{P}=0.003)$. The ConAinduced DNA synthesis obtained with various concentrations of the lectin showed a normal dose-effect pattern in all four study groups (figure 2). In comparison with the level in the reference group, a somewhat lower average DNA synthesis was observed in the allergy group during stimulation with 10 and $20 \mu \mathrm{g}$ of ConA, and in the amalgam group during stimulation with 10,20 and $40 \mu \mathrm{g}$ ConA. The 


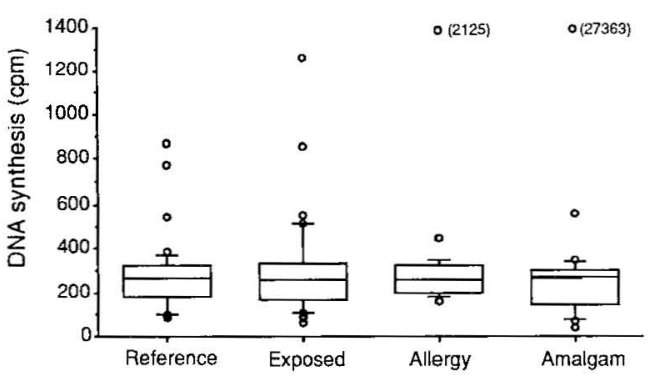

Figure 1. Box plots showing spontaneous lymphocyte deoxyribonucleic acid (DNA) synthesis in the four study groups. The 10th, 25th, 50th, 75 th and 90 th percentiles are indicated. $(\mathrm{cpm}=$ counts per minute)

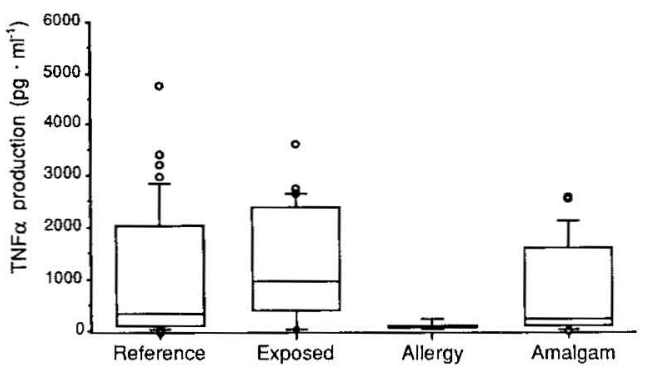

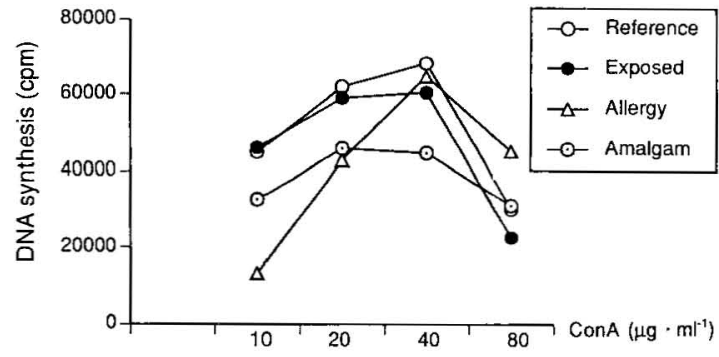

Figure 2. Average lymphocyte deoxyribonucleic acid (DNA) synthesis induced by concanvalin $A$ (ConA) in the four study groups. (cpm = counts per minute)

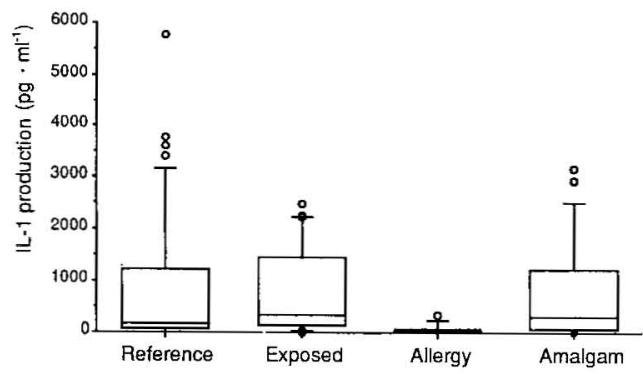

Figure 3. Box plots showing in vitro production of tumor necrosis factor alpha (TNF $\alpha$ ) and interleukin 1 (IL-1) in the four study groups. The 10th, 25th, 50th, 75th and 90th percentiles are indicated (the TNF $\alpha$ and IL-1 values of one subject were lacking from the exposed group).

results from one sampling occasion (comprising three referents and six subjects in the amalgam group) showed a strong deviation; therefore these values were excluded from the statistical analyses (and from figure 2).

\section{Cvtokines}

Only a few individuals showed detectable serum levels of IL-6. The median value was zero in all four groups, and the ranges were $0-30 \mathrm{pg} \cdot \mathrm{ml}^{1}$ in the reference group, $0-30 \mathrm{pg} \cdot \mathrm{ml}^{-1}$ in the exposed group, $0-0 \mathrm{pg} \cdot \mathrm{ml}^{\prime}$ in the allergy group, and $0-$ $25 \mathrm{pg} \cdot \mathrm{ml}^{-1}$ in the amalgam group. Serum samples from patients with sepsis $(\mathrm{N}=6)$, analyzed simultaneously at the same laboratory, showed considerably higher concentrations $\left(>1000 \mathrm{pg} \cdot \mathrm{ml}^{-1}\right)$.

The in vitro production of IL- 1 and TNF $\alpha$ was within normal ranges (compared with those of reference persons and patients examined earlier at the same laboratory) in virtually all of the subjects, but the level of both TNF $\alpha$ and IL-1 was notably lower $(P=0.01)$ in the allergy group than in the referents (figure 3). Within the group occupationally exposed to mercury, there were weak, but statistically significant tendencies towards negative correlations between the mercury concentrations in blood and urine and the in vitro production of both TNF $\alpha$ and IL-1. However, these tendencies faded when the sampling occasion was included in the statistical analysis (ANOVA). None of the other indicators of mercury exposure correlated with the levels of TNF $\alpha$ and IL-1.

In the reference group, both TNF $\alpha$ and IL-1 correlated negatively with age $(\mathrm{r}=-0.32, \mathrm{P}=0.050$ and $\mathrm{r}=-0.43, \mathrm{P}=0.006$, respectively). The corresponding correlations were less marked in the three target groups, but statistically significant in the total population $(r=-0.28, P=0.03$ and $r=-0.29, P=0.03$, respectively). The smokərs exhibited a lower production of TNF $\alpha(P=0.05)$ and IL-1 $(P=0.02)$ than the nonsmokers.

\section{Lymphocyte surface markers}

The mononuclear cells from subjects in all four groups showed negligible expression of IL-2 receptors. Neither the number of cells with class II antigens nor the $\mathrm{CD} 4: \mathrm{CD} 8$ ratio differed particularly between the groups. Further studies on various lymphocyte surface markers are in progress, and the results will be reported separately.

\section{Lymphocyte transformation tests}

The LTT was negative in all of the tested subjects occupationally exposed to mercury $(\mathrm{N}=10)$. In the allergy group five subjects (out of the 9 tested) 
showed a positive reaction to mercuric chloride. Two of these five persons also had a positive reaction to phenylmercury acetate. In the amalgam group, one subject (out of the 10 tested) showed a positive reaction to both mercury compounds.

\section{Selenium}

The plasma selenium concentrations were within normal ranges, and there were no significant correlations between the selenium levels and the immunologic parameters or mercury levels in blood or urine. Details regarding the analyses of plasma selenium and the erythrocyte activity of glutathione peroxidase and catalase have been reported separately (17).

Analyses of the total population $(\mathrm{N}=110)$ by means of multiple regression and ANOVA did not show any significant correlations between the different immune parameters and the mercury exposure estimates. The amalgam burden was not related to the immunologic parameters. Nor did fish intake, alcohol consumption, or gender influence these parameters.

\section{Discussion}

In the present study, the hypothesis that persons exposed to low levels of inorganic mercury exhibit immunologic manifestations has been evaluated with an extensive test battery. Thus the tests applied should be expected to detect disturbances of different functional aspects of the immune system, including activation, immunodeficiency, autoimmunity, and allergy.

Some of the tests used, especially the determinations of DNA synthesis and in vitro cytokine production, may be susceptible to the transportation and preparation of blood samples. Therefore, the sampling procedure and the preparation of blood samples were standardized as far as possible. Both the "target" subjects and the referents were included in every sampling occasion, and the sampling occasion was included in the statistical analyses (ANOVA). The results from one sampling episode showed a strong deviation in the ConA-induced DNA synthesis; therefore these values were all excluded. A tendency towards decreased in vitro production of TNF $\alpha$ and IL-1 was noticed among both the mercury-exposed subjects and the referents on one sampling occasion, which made the negative correlations between the mercury levels in blood and urine and the cytokine production observed in the mercury-exposed group less convincing.

The mercury-exposed workers were selected to include both persons with high and persons with low exposure. According to the observed mercury levels in blood and urine, the degree of current exposure in this group was rather low. However, the duration of exposure had been long (average 20 years), and the exposure levels had been higher earlier, especially in the chloralkali factory. The cross-sectional study design may also have included a "healthy worker" effect (ie, subjects with health problems related to their occupational exposure may have quit). According to the companies' health care units, however, there had been very low worker turnover in the different plants.

The selection of subjects into the amalgam group was a difficult task, as dental amalgam is not generally accepted as an etiologic factor for disease. Some individuals with medically unexplained, widespread symptoms have claimed an exceptional susceptibility to mercury released from their own amalgam fillings and insisted on further investigation of possible mercury intoxication.

The criteria for our amalgam group selected persons with many and severe symptoms. Some of these symptoms are described as the chronic fatigue syndrome. The subjects in our amalgam group did not, however, report fever, lymph-node pain, or pharyngitis, which are primary criteria for the chronic fatigue syndrome. All of the subjects had earlier been examined by physicians and dentists, and therefore evident medical or odontological causes of their illness were excluded. This selection procedure probably excluded persons with rheumatologic disorders and collagenosis and may explain the relatively low (compared with the referents) prevalence of serum autoantibodies to some of the antigens tested. The prevalence of antithyroid antibodies was, however, slightly elevated in comparisons with the referents. The data on health history revealed that two of the subjects with antithyroid antibodies in serum had earlier undergone medical investigations due to goiter. This finding suggested that possibly some persons who attribute their illness to dental amalgam fillings may suffer (or have suffered) from thyroid gland disease.

Other than the decreased in vitro production of TNF $\alpha$ and IL-l observed in the allergy group, our results revealed no marked differences between the three target groups and the reference group regarding white blood cell counts, immunoglobulins, autoantibodies and IL-6 in serum, spontaneous and ConA-induced DNA synthesis, and the expression of lymphocyte activation markers. In addition, the data argue against any specific sensitization against mercury in the group occupationally exposed to mercury or the amalgam group, although more information is required to establish this as a fact.

A suspected effect of dental amalgam and nickel alloys on $\mathrm{T}$ lymphocytes, has earlier been reported by Eggleston (22), and elevated levels of serum proteins in mercury-exposed workers was reported by Bencko et al (23). An increased prevalence of antilaminin antibodies among mercury-exposed workers was reported by Lauwerys and his co-workers (24), but it was not confirmed in a later study by the same 
group of researchers (25). Langworth et al (26) found no differences in the serum immunoglobulin concentration or the prevalence of serum autoantibodies (including antiglomerular basement membrane and antilaminin antibodies) between chloralkali workers exposed to mercury vapor and unexposed referents.

Spontaneous DNA synthesis in lymphocytes has been reported to be elevated in patients with connective tissue disorders $(27,28)$, allergy (29), infections $(19,30)$, and malignant tumors (31). IL-6 in serum also exhibits elevation in acute and chronic inflammation and in septic shock and injury $(32,33)$. The expression of lymphocyte activation markers such as IL-2 receptors and human leucocyte antigen-DR has been applied so that clinical conditions associated with immune activation, for example, in chronic fatigue syndrome, could be evaluated $(34,35)$.

According to our results it seems unlikely that persons with low-level occupational exposure to mercury or with health disturbances attributed to amalgam fillings display any easily detectable immunologic disturbance due to their mercury exposure. However, one individual in the amalgam group exhibited antinuclear antigen antibodies in serum and a markedly augmented spontaneous DNA synthesis. An extended clinical examination (including laboratory tests) did not reveal any rheumatologic disease, collagenosis, or malignancy in this individual.

The lower in vitro production of both TNF $\alpha$ and IL- 1 noted for the allergy group suggests that a suppression of cytokine production may be associated with mercury hypersensitivity. This finding is interesting, as impaired mitogen-induced cytokine production (IL-2) has been described for BN rats exposed to mercuric chloride (36), and it needs further investigation. Furthermore, the DNA response in this group was lower than in the referents' during stimulation with $10 \mu \mathrm{g}$ of $\mathrm{Con} A$, and this difference may point to a possible impairment in T-cell function. The allergy group, however, differed somewhat in the background parameters (age, alcohol consumption, smoking, amalgam surfaces) when compared with the reference group (table 1). Therefore the findings must be interpreted with caution.

In the reference group, spontaneous DNA synthesis, as well as TNF $\alpha$ and IL- 1 production, negatively correlated with age $(\mathrm{P}=0.015, \mathrm{P}=0.004$, and $\mathrm{P}=0.001$, respectively). The noted relations indicate a decline in immune activity with increasing age, which may be reasonable. Such relationships were, however, not seen in the other three study groups and is not, to our knowledge, supported by other reports.

In the total population ( $N=110)$, none of the immune parameters correlated with the mercury exposure indicators. Thus amalgam burden was not related to any sign of immunologic disturbance. Smoking has been shown to influence serum immunoglobulin levels (37) and also the activity of natural killer cells (38). A negative correlation between the in vitro production of TNF $\alpha$ and IL- 1 and smoking, as seen in our study, has not been reported earlier.

Taken together, the results argue against a doserelated effect of inorganic mercury on the human immune system. The absence of immunologic disturbances among the mercury-exposed workers implies that the immune system of the majority of individuals is insensitive to low-level exposure to inorganic mercury or tolerates it. Nevertheless, not all individuals are insensitive to low-dose mercury exposure. Dose-response and dose-effect estimations in immunotoxicology are complicated (39), and it is well known from animal models that genetically restricted factors predispose a person to the development of mercury-induced autoimmune phenomena (2). Genetic factors also seem to predispose a person to autoimmune diseases induced by drugs or occupational chemicals (40).

It must be considered that the relatively small size of the study groups limited the general significance of our results. Thus it is hard to rule out small effects of mercury exposure on the human immune system. It must also be emphasized that many of the immune reactions seen in rodents are transient and disappear after a few weeks, despite persisting mercury exposure. It has not been studied whether such temporary immune reactions can occur in workers at the onset of their exposure to mercury.

Still, as there may exist certain individuals with a "high" sensitivity to low doses of inorganic mercury, further studies on the possible immunologic effects of this metal are important. Studies of immune effects at higher exposure levels and on larger populations are required for a better evaluation of the potential dose-response relationships and for more extensive conclusions to be drawn.

\section{Acknowledgments}

We thank Ms E Thunberg and Ms G-B Roos for their general assistance, including the blood sampling, and Mr E Söderman for his statistical advice. Appreciated chemical analyses were carried out by $\mathrm{Ms} A$ Nilsson and Ms E Bergdahl (autoantibodies, lymphocyte markers, DNA synthesis, cytokines), and Dr V Stejskal (LTT).

Financial support was received from the Swedish Work Environment Fund and the Swedish Medical Research Council.

\section{References}

1. Berlin M. Mercury. In: Friberg L, Nordberg GF, Vouk VB, ed. Handbook on the toxicology of metals; vol II. Amsterdam: Elsevier, 1986:387-445.

2. Pelletier L, Hirsch F, Rossert J, Druet E, Druet P. Experimental mercury-induced glomerulonephritis. Semin Immunopathol 1987;9:359-69.

3. Sapin $C$, Druet $E$, Druet P. Induction of antiglomerular basement membrane antibodies in brown Norway 
rat by mercuric chloride. Clin Exp Immunol 1977;28: $173-9$.

4. Druet P, Druet E, Potdevin F, Sapin C. Immune type glomerulonephritis induced by $\mathrm{HgCl} 2$ in the Brown Norway rat. Ann Immunol 1978;129C:777-92.

5. Prouvost-Danon A, Abadie A, Sapin C, Bazin H, Druet $P$. Induction of IgE synthesis and potentiation of antiovalbumin $\mathrm{IgE}$ antibody response by $\mathrm{HgCl} 2$ in the rat. J Immunol 1981;126:699-702.

6. Hirsch F, Couderc J, Sapin C, Fournie G, Druet P. Polyclonal effect of $\mathrm{HgCl} 2$ in the rat and its possible role in an experimental autoimmune disease. Eur J Immunol 1982;12:620-5.

7. Robinson GCJ, Balazs T, Egorov IK. Mercuric chloride, gold sodiumthiomalate, and D-penicillamine-induced antinuclear antibodies in mice. Toxicol Appl Pharmacol 1986;86:159-69.

8. Hultman P, Eneström S. The induction of immune complex deposits in mice by peroral and parenteral administration of mercuric chloride: strain dependent susceptibility. Clin Exp Immunol 1987;67:283--92.

9. Hultman P, Eneström S. Mercury induced antinuclear antibodies in mice: characterization and correlation with renal immune complex deposits. Clin Exp Immunol 1988;71:269--74.

10. Burrows D. Hypersensitivity to mercury, nickel and chromium in relation to dental materials. Int Dent J 1986;36:30-4.

11. North American Contact Dermatitis Group. Epidemiology of contact dermatitis in North America. Arch Dermatol 1972;108:537-40.

12. Kazantzis G, Schiller FR, Asscher AW, Drew RG. Albuminuria and the nephrotic syndrome following exposure to mercury and it compounds. Q J Med 1962; 31:403--18.

13. Barr RD, Rees PH, Cordy PE, Kungu A, Woodger BA, Cameron $\mathrm{H}$. Nephrotic syndrome in adult Africans in Nairobi. Br Med J 1972;2:131-4.

14. Filliastre J-P, Druet P, Mery J-P. Proteinuric nephropathies associated with drugs and substances of abuse. In: Cameron JS, Glassok RJ, ed. The nephrotic syndrome. New York, Basel: Marcel Dekker Inc, 1988: $697-742$.

15. Weiner J, Nylander M, Berglund F. Does mercury from amalgam restorations constitute a health hazard? Sci Total Environ 1990;99:1-22.

16. World Health Organization (WHO). Inorganic mercury. Geneva: WHO, 1991. (Environmental health criteria; no 118.)

17. Björkman L, Langworth S, Lind B, Elinder C-G, Nordberg M. Activity of antioxidative enzymes in erythrocytes and concentration of selenium in plasma related to mercury exposure. J Trace Elem Electrol Health Dis. In press.

18. Langworth $\mathrm{S}$. Early effects of occupational and environmental exposure to inorganic mercury [dissertation]. Stockholm: Karolinska Institute, 1992. ISBN 91628-0691-2.

19. Soop M, Soop A, Sundqvist KG. Spontaneous lymphocyte proliferation during trauma and infection. Scand J Immunol 1988;28:659-65.

20. Stejskal VDM, Forsbeck M, Nilsson R. Lymphocyte transformation test for diagnosis of isothiazolinon allergy in man. J Invest Dermatol 1990;94:798 —802.

21. Vesterberg O. Automatic method for quantitation of mercury in blood, plasma and urine. J Biochem Biophys Methods 1991;23:227-35.

22. Eggleston DW. Effect of dental amalgam and nickel alloys on T-Iymphocytes: preliminary report. J Prosthet Dent 1984;51:617-23.

23. Bencko V, Wagner V, Wagnerova M, Ondrejcak V. Immunological profiles in workers occupationally exposed to inorganic mercury. J Hyg Epidemiol Microbiol Immunol 1990;34:9-15.
24. Lauwerys R, Bernard A, Roels H, Buchet JP, Gennart JP, Mahieu P, et al. Anti-laminin antibodies in workers exposed to mercury vapour. Toxicol Lett $1983 ; 17: 113-6$.

25. Bernard AM, Roels HR, Foidart JM, Lauwerys RL. Search for anti-laminin antibodies in the serum of workers exposed to cadmium, mercury vapour or lead. Int Arch Occup Environ Health 987;59:303-9.

26. Langworth S, Elinder C-G, Sundkvist K-G, Vesterberg $O$. Renal and immunological effects of occupational exposure to inorganic mercury. Br J Ind Med 1992; 49:394-401.

27. Glinski W, Gershwin ME, Budman DR, Steinberg AD. Study of lymphocyte subpopulations in normal humans and patients with systemic lupus erythematosus by fractionation of peripheral blood lymphocytes on a discontinuous gradient. Clin Exp Immunol 1976;26:22838.

28. al-Balaghi S, Ström H, Möller E. Spontaneous DNA synthesis in rheumatoid arthritis: evidence of enhanced circulating non-T-cell proliferation. Scand J Immunol 1983; 17:521-30.

29. Gill FA. The association of increased spontaneous lymphocyte transformation in vitro with clinical manifestations of drug hypersensitivity. $J$ Immunol 1967;98:778-85.

30. MacKinney AAJ. Tissue culture of cells already in DNA-synthesis from patients with infectious mononucleosis. Blood 1965;26:36-48.

31. Heier HE, Godal T. DNA-synthesis in unstimulated blood lymphocytes of patients with untreated malignant lymphomas or other malignant tumors. Scand $\mathbf{J}$ Haematol 1977;18:149-53.

32. Hack CE, De Groot ER, Felt-Bersma RIF, Nuijens IH, Strack Van Schundel RJM, Eerenberg-Belmer AIM, et al. Increased plasma levels of interleukin-6 in sepsis. Blood 1989;74:1704-10.

33. Fong $Y$, Moldawe L, Shires T, Lowry SF. The biologic characteristics of cytokines and their implication in surgical injury. Surg Gynecol Obstet 1990;170: $363-78$.

34. Stein H, Schwarting R, Niedobitek GDF. Activation section report. In: Knapp W, ed. Leucocyte typing IV. London: Oxford University Press, 1989:387-513.

35. Landay AL, Jessop C, Lennette ET, Cevy JA. Chronic fatigue syndrome: clinical condition associated with immune activation. Lancet 1991;338:707--12.

36. Baran D, Lantz O, Dosquet P, Sfaksi A, Druet P. Interleukin-2 production in Brown-Norway rats with $\mathrm{HgCl}_{2}$-induced autoimmune disease: paradoxical in vivo versus in vitro findings. Clin Exp Immunol 1988;73:401-5.

37. Warren CP, Holford-Strevens V, Wong C, Manfreda $\mathrm{J}$. The relationship between smoking and total immunoglobulin $\mathrm{E}$ levels. J Allergy Clin Immunol 1982;69:370-375.

38. Ferson M, Edwards A, Lind A, Milton GW, Hersey P. Low natural killer-cell activity and immunoglobulin levels associated with smoking in human subjects. Int J Cancer 1979;23:603--609.

39. Nicklin S, Miller K. Dose-effect and dose-response in immuno-toxicology: problems and conceptual considerations. In: Dayan AD, Hertel RF, Heseltine E, Kazantzis G, Smith EM, Van der Venne MT, ed. Immunotoxicity of metals and immunotoxicology. New York and London: Plenum Press, 1991:43-56.

40. Gleichmann E, Kimber I, Purchase IFH. Immunotoxicology: suppressive and stimulatory effects of drugs and environmental chemicals on the immune system. Arch Toxicol 1989;63:257-73.

Received for publication: 22 June 1992 